\title{
Growth Performance of Hypophthalmichthys molitrix and Barbodes gonionotus Fingerlings by Feeding Microalgae Cultured on Fertilizer Factory Effluent
}

\author{
M. A. Toyub ${ }^{a *}$, M. I. Miah ${ }^{b}$ and M. A. B. Habib \\ ${ }^{a}$ Department of Fisheries, Ministry of Fisheries and Live stock, Bangladesh and ${ }^{b}$ Faculty of Fisheries, \\ Bangladesh Agricultural University, Mymensingh Bangladesh
}

\begin{abstract}
Growth performance of Hypophthalmichthys molitrix (Silver carp) and Barbodes gonionotus (Sar puti) fingerlings were studied separately in aquaria by feeding cultured microalgae (Chlorella ellipsoidea, Scenedesmus obliquus and Spirulina platensis) in different combinations for a period of 21 days. Fertilizer factory effluent was used to grow these microalgae. Significantly $(\mathrm{p}<0.05)$ higher weight gain of $H$. molitrix (81.16\%), was in the treatment $\mathrm{T}_{2}$ (Rearing by feeding $100 \%$ S. platensis) and the minimum percentage (- $\left.4.29 \%\right)$ was obtained in the control (fed on fishmeal and mustered oil cake). Specific growth rate (SGR, \%/day) of H. molitrix were determined - 0.21 to 2.84 for all the treatments which was significantly $(\mathrm{p}<0.05)$ higher in $\mathrm{T}_{2}$. Survival rate of H. molitrix was 25.90 to $77.80 \%$. In the case of $B$. gonionotus, significantly $(\mathrm{p}<0.05)$ higher weight gain $(149.10 \%)$ was observed in $\mathrm{t}_{2}$ (Rearing by feeding $100 \%$ S. platensis). The SGR $(\% /$ day) of B. gonionotus were ranged from 2.25 to 4.33 which was significantly $(\mathrm{p}<0.05)$ higher in $\mathrm{t}_{2}$ than all other treatment except control. Survival rate of B. gonionotus was ranged from $97.78 \%$ to $100 \%$. The reared fingerlings were found nutritionally rich.
\end{abstract}

Key words: Fingerlings, Microalgae, Growth performance, Specific growth rate.

\section{Introduction}

Hypophthalmichthys molitrix and Barbodes gonionotus are exotic fish, which are locally known as silver carp and Thai sharpunti, respectively. They are very popular as table fish in Bangladesh for their palatability and good taste, and their fast growth and high yield. As they become marketable size within short time, fish farmers prefer to these species. So, the demand of fry and fingerlings of these species are increasing day by day. Though, the seed production increasing now a days but the supply of fingerlings are not sufficient, as the rearing technique of this stage is not improved due to appropriate feed resulting high mortality. To make fish fingerlings readily available to the fish farmers, we need to develop an appropriate technology for large-scale production of fish fingerlings. Feed cost is one of the most important largest operational costs in aquaculture (De Silva and Davy, 1992). It is very difficult to supply of natural live food when large quantities of fish fry are reared. It is interesting to note that fish are fed higher precentage of protein in their diet than land animals (Lovell, 1991). The alga, Chlorella contains long chain polyunsaturated fatty acids (PUFA), which make it a valuable food for marine invertebrates and fish (Watanabe et al., 1983). It is recorded that the presence of Chlorella improved the growth and survival of 40 species of fishes studied (Jhons, 1970). The protein content of Chlorella is appreciable higher ( $50 \%$ of the dry weight) than that of the best vegetable sources of protein used in animal feed (Bhanou and Vass 1973). According to Yap et al. (1982) still the highest proportion of the protein (33\%) can be replaced by Spirulina or Chlorella without negative symptoms. Microalgae have been used as live food in intensive hatchery systems (Walne, 1981). Microalgae not only play an important role in aquaculture as a food source but together with bacteria they also have an important role in dissolved oxygen and carbon dioxide balance in the water (Pruder, 1983). Successful laboratory rearing will help to develop culture techniques of the fish fingerlings. Therefore, considering all these in mind, the present study was undertaken to rear $H$. molitrix and B. gonionotus fingerlings in laboratory condition feeding cultured microalgae and to analyze the nutritional values of the fishes.

\section{Materials and Methods}

\section{Preparation of Media and Culture of Microalgae}

Fertilizer factory effluent (FFE) was used to grow the Chlorella ellipsoidea, Scenedesmus obliquus and Spirulina

\footnotetext{
* Corresponding author: E-mail:
} 
platensis. Among the three microalgae Chlorella ellipsoidea and Scenedesmus obliquus that was used for mass culture was isolated earler and pure culture was mainained in the laboratory (Live Food Culture Laboratory, Department of Aquaculture, Bangladesh Agricultural University, Mymensingh) by authors. On the other hand Spirulina platensis was initially collected from the University of Putra, Malaysia and pure culture was maintained by the authors in the same laboratory. The FFE was collected from Jamuna Fertilizer Factory (urea), Jamalpur. The collceted FFE was diluted at 50\% level by tap water and decomposed for a period of 15 days by aeration. Hundred-liter capacity aquarium was used for the continuous culture of C. ellipsoidea, $S$. obliquus and $S$. platensis in prepared FFE medium. The aquaria were set in the balcony of Live food Culture Laboratory under natural light and temperature. Six aquaria were set for each species of microalgae. After successful growth of microalgae rearing of fingerlings were started. The same amount of FFE medium was added regularly in the aquaria which were removed at the time of collection of microalgae for fingerlings. Prior to rearing of fingerlings the proximate composition of cultured algae were analyzed (Horwitx, 1984).

\section{Culture of Fish Fingerlings}

Culture of Fish Fingerlings was performed in two steps for a period of three weeks of each species in the Live Food Culture Laboratory of the Faculty of Fisheries, Bangladesh Agricultural University Mymensingh. In the first step, attempt was taken to rear $H$. molitrix (where the treatments are mentioned as $T_{1}-T_{8}$ ) and in the second step, attempt was

Table I: Combination of different species of microalgae and artificial diet for rearing of $H$. molitrix $\left(T_{1}\right.$. $T_{8}$ ) and B. gonionotus $\left(t_{1-} t_{8}\right)$ fingerlings

\begin{tabular}{lcccc}
\hline $\begin{array}{l}\text { Sl. } \\
\text { No. }\end{array}$ & Treatments & $\begin{array}{c}\text { Scenedesmus } \\
\text { obliques } \\
(\%)\end{array}$ & $\begin{array}{c}\text { Spirulina } \\
\text { platensis } \\
(\%)\end{array}$ & $\begin{array}{c}\text { Chlorella } \\
\text { ellipsoidea } \\
(\%)\end{array}$ \\
\hline 1 & $\mathrm{~T}_{1} \& \mathrm{t}_{1}$ & 100 & - & - \\
2 & $\mathrm{~T}_{2} \& \mathrm{t}_{2}$ & - & 100 & - \\
3 & $\mathrm{~T}_{3} \& \mathrm{t}_{3}$ & - & - & 100 \\
4 & $\mathrm{~T}_{4} \& \mathrm{t}_{4}$ & 33.33 & 33.33 & 33.33 \\
5 & $\mathrm{~T}_{5} \& \mathrm{t}_{5}$ & 50 & 25 & 25 \\
6 & $\mathrm{~T}_{6} \& \mathrm{t}_{6}$ & 25 & 50 & 25 \\
7 & $\mathrm{~T}_{7} \& \mathrm{t}_{7}$ & 25 & 25 & 50 \\
& $\mathrm{~T}_{8} \& \mathrm{t}_{8}$ & \multicolumn{4}{c}{} \\
8 & $($ Control) & $50 \%$ fishmeal and 50\% mustard oil cake \\
\hline
\end{tabular}

made to rear B. gonionotus (where the treatments are mentioned as $T_{1}-T_{8}$ ) in aquaria. In both steps of experiment, the fingerlings were fed with cultured microalgae (C. ellipsoidea, S. obliquus and S. platensis) of seven different combinations (Table I) having control (feeding fishmeal and mustered oil cake). The feeds were supplied twice daily at the rate of $5 \%$ of body weight of the fingerlings in both steps of experiment.

Fingerlings of $H$. molitrix (21 days old) were collected from local government (Maskanda) fish seed farm and $B$. gonionotus (35 days old) were collected from the nursery pond situated in the hatchery complex of Bangladesh Agricultural University (BAU) campus, Mymensingh. The fingerlings were reared in aquaria containing $30 \mathrm{~L}$ water in each, and the density of the fingerlings was one fish per 2.0 $\mathrm{L}$ of water. Before stocking in the experimental aquaria, acclimatization of fingerlings was done for a period of three days in 6 aquaria at a density of 70 fish per aquarium. In each step of experiment three replications were used both for control and microalgae feeding culture. The experiment was designed to fit to the CRD (Completely Randomized Design) (Gomez and Gomez 1976). The fingerlings were allowed to fed with cultured microalgae twice daily at the rate of $5 \%$ of body weight. Weight of cultured microalgae Chlorella ellipsoidea and Scenedesmus obliquus was calculated on the basis of $\mathrm{OD}_{620}=2.5-3.1,0.80-0.95 \mathrm{~g} / 1$ dry biomass (Habib et al., 2003). On the other hand for determining the weight of cultured Spirulina platensis samples were filtered with filter paper (Whatman, GF/C) and shifted to the oven at $70^{\circ} \mathrm{C}$ for 24 hours. The samples were then transferred to the dessicator for cooling and weight was measured using an electric balance. Before filtering the weight of the dried filter paper was taken. And the weight was calculated by the following formula:

Cell weight $(\mathrm{mg} / 1)=$ Weight of the filter paper with sample - Weight of the filter paper without sample before filtering

Sufficient dissolved oxygen was ensured providing air pump in plastic tubing. Temperature, $\mathrm{pH}$ and dissolved oxygen (DO) of the water were determined every alternate day by respective meter. Weight $(\mathrm{g})$ and length $(\mathrm{cm})$ of fish fingerlings were determined once in a week by an electrical balance and a centimeter scale, respectively. 
Estimation of Specific Growth Rate (SGR, \%/day) of Fingerlings

Specific growth rate (SGR, \%/day) of fingerlings were calculated by the following equation (Brown, 1957) :

SGR (\%/day) ) $\frac{\mathrm{LnW}_{2}-\mathrm{LnW}_{1}}{\mathrm{~T}_{2}-\mathrm{T}_{1}} \times 100$

Where,

$\mathrm{W}_{1}=$ the initial live body weight (g) at time $\mathrm{T}_{1}$ day

$\mathrm{W}_{2}=$ the initial live body weight (g) at time $\mathrm{T}_{2}$ day

\section{Analysis of Proximate Composition}

Dried samples of reared fish were analyzed for proximate composition following the standard methods of Horwitz (1984) in the Fish Nutrition Laboratory of the Department of Aquaculture, BAU, Mymensingh.

\section{Statistical Analysis}

Mean and standard deviations were calculated. Then the data were analyzed through an one-way ANOVA test using SPSS followed by Duncan's Multiple Range Test (Zar, 1984).

\section{Results and Discussion}

In the case of rearing of $H$. molitrix (where the treatments are mentioned as $\mathrm{T}_{1}-\mathrm{T}_{8}$ ) the maximum weight gain (\%) obtained in treatment $\mathrm{T}_{2}$ (feeding $100 \%$ S. platensis) and the minimum was obtained in the control $\left(\mathrm{T}_{8}\right)$. feeding $50 \%$ fishmeal and $50 \%$ mustard oil cake. However, negative weight gain $(-4.29 \%)$ was observed in control. Specific growth rate (SGR, \%/day) were 1.97, 2.84, 1.60, 2.15, 1.28, 1.78, 1.33 and -0.21 in treatments $T_{1}-T_{8}$, respectively (Table II).
Significantly $(\mathrm{p}<0.05)$ higher survival rate $(77.80 \%)$ was observed in $T_{2}$ than others while $T_{8}$ showed the least (25.90\%). Negative growth indicates that $H$. molitrix didn't ingest supplied artificial diet. The SGR of the treatment $T_{2}$, feeding with $100 \%$ S. platensis was significantly $(\mathrm{p}<0.05)$ higher than other treatments. The maximum weight gain (g) was determined 0.56 in $\mathrm{T}_{2}$ followed by $0.39,0.35,0.320 .28$, 0.23, 0.22 and -0.03 in $\mathrm{T}_{4}, \mathrm{~T}_{1}, \mathrm{~T}_{6}, \mathrm{~T}_{3}, \mathrm{~T}_{7}, \mathrm{~T}_{5}$ and $\mathrm{T}_{8}$, respectively (Fig. 2). The length gain showed the similar trend (Fig. 1). The survival rate was also the maximum in treatment $\mathrm{T}_{2}$ and was significanlty $(\mathrm{p}<0.05)$ higher than other treatments (Table II). The findings of the present study regarding different growth parameters illustrate that $H$. molitrix fingerlings of treatment $\mathrm{T}_{2}$ showed significantly $(p<0.05)$ higher growth performance than other treatments. It may be happened due to the higher protein content of supplied S. platensis. Fish fry basically need high protein rich live foods for their development and because of that many researchers have been worked on the protein requirements of fish (Kaushik, 1992). But the overall growth performance of H. molitrix was not satisfactory. Live foods sometimes do not give good growth and survival rate of fish fry (Ozkizilcik and Chu, 1994).

During the rearing of $H$. molitrix fingerling, $\mathrm{pH}$ and dissolved oxygen (DO) ranges of water in the aquaria were 7.16 to 8.25 and 4.77 to $7.17 \mathrm{mg} / 1$, respectively which were in suitable range. On the other hand during the study period the temperature range was 27.57 to $30.63^{\circ} \mathrm{C}$ which was also within the suitable range of fish culture (Azim et al., 1995 and Wahid et al., 1997).

In case of rearing of $B$. gonionotus (where the treatments are mentioned as $T_{1}-T_{8}$ ) the maximum weight gain $149.10 \%$

Table II: Growth performance and survival rate of reared $H$. molitrix fed on cultured microalgae in different combination

\begin{tabular}{l|c|c|c|c|c|c}
\hline Treatments & $\begin{array}{c}\text { Weight } \\
\text { gain }(\mathrm{g})\end{array}$ & $\begin{array}{c}\text { Weight } \\
\text { gain \% }\end{array}$ & $\begin{array}{c}\text { Length } \\
\text { gain }(\mathrm{cm})\end{array}$ & $\begin{array}{c}\text { Length } \\
\text { gain \% }\end{array}$ & $\begin{array}{c}\text { SGR } \\
(\% / d a y)\end{array}$ & $\begin{array}{c}\text { Survival } \\
\text { rate }(\%)\end{array}$ \\
\hline $\mathrm{T}_{1}$ & $0.35 \pm 0.04^{\mathrm{bc}}$ & $50.73 \pm 0.03^{\mathrm{c}}$ & $0.61 \pm 0.13^{\mathrm{b}}$ & $13.70 \pm 0.08^{\mathrm{d}}$ & $1.97 \pm 0.30^{\mathrm{b}}$ & $51.10 \pm 5.85^{\mathrm{c}}$ \\
$\mathrm{T}_{2}$ & $0.56 \pm 0.02^{\mathrm{a}}$ & $81.16 \pm 0.03^{\mathrm{a}}$ & $0.80 \pm 0.03^{\mathrm{a}}$ & $17.54 \pm 0.03^{\mathrm{a}}$ & $2.84 \pm 0.16^{\mathrm{a}}$ & $77.80 \pm 5.54^{\mathrm{a}}$ \\
$\mathrm{T}_{3}$ & $0.28 \pm 0.06^{\mathrm{cd}}$ & $40.00 \pm 0.04^{\mathrm{e}}$ & $0.60 \pm 0.13^{\mathrm{b}}$ & $13.48 \pm 0.09^{\mathrm{e}}$ & $1.60 \pm 0.43^{\mathrm{bc}}$ & $51.10 \pm 3.85^{\mathrm{c}}$ \\
$\mathrm{T}_{4}$ & $0.39 \pm 0.05^{\mathrm{b}}$ & $56.52 \pm 0.04^{\mathrm{b}}$ & $0.73 \pm 0.06^{\mathrm{ab}}$ & $16.30 \pm 0.05^{\mathrm{b}}$ & $2.15 \pm 0.39^{\mathrm{b}}$ & $55.60 \pm 4.45^{\mathrm{c}}$ \\
$\mathrm{T}_{5}$ & $0.22 \pm 0.06^{\mathrm{d}}$ & $30.56 \pm 0.05^{\mathrm{g}}$ & $0.57 \pm 0.16^{\mathrm{b}}$ & $12.70 \pm 0.09^{\mathrm{f}}$ & $1.28 \pm 0.34^{\mathrm{c}}$ & $53.30 \pm 6.67^{\mathrm{c}}$ \\
$\mathrm{T}_{6}$ & $0.32 \pm 0.06^{\mathrm{bc}}$ & $45.71 \pm 0.05^{\mathrm{d}}$ & $0.66 \pm 0.06^{\mathrm{b}}$ & $14.80 \pm 0.05^{\mathrm{c}}$ & $1.78 \pm 0.32^{\mathrm{bc}}$ & $64.40 \pm 3.85^{\mathrm{b}}$ \\
$\mathrm{T}_{7}$ & $0.23 \pm 0.09^{\mathrm{d}}$ & $32.86 \pm 0.08^{\mathrm{f}}$ & $0.56 \pm 0.04^{\mathrm{b}}$ & $12.56 \pm 0.06^{\mathrm{f}}$ & $1.33 \pm 0.14^{\mathrm{c}}$ & $53.30 \pm 3.57^{\mathrm{c}}$ \\
$\mathrm{T}_{8}$ & $-0.03 \pm 0.01^{\mathrm{e}}$ & $-4.29 \pm 0.01^{\mathrm{h}}$ & $0.01 \pm 0.01^{\mathrm{c}}$ & $0.22 \pm 0.01^{\mathrm{g}}$ & $-0.21 \pm 0.01^{\mathrm{d}}$ & $25.90 \pm 5.54^{\mathrm{d}}$ \\
\hline
\end{tabular}

Data in a column followed by different letter (s) indicate significant differences at $5 \%$ level 


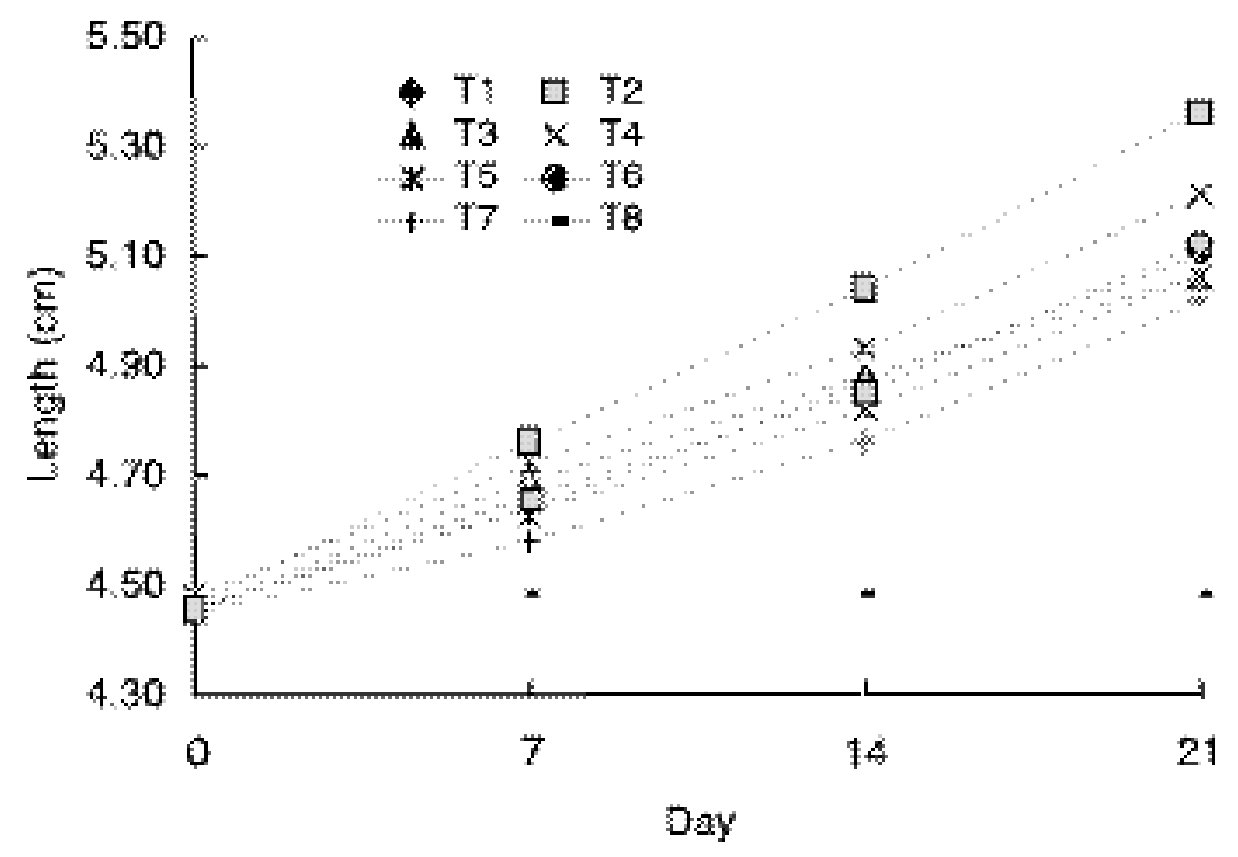

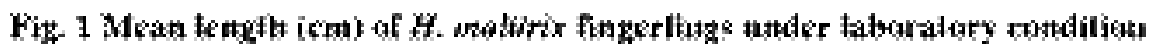

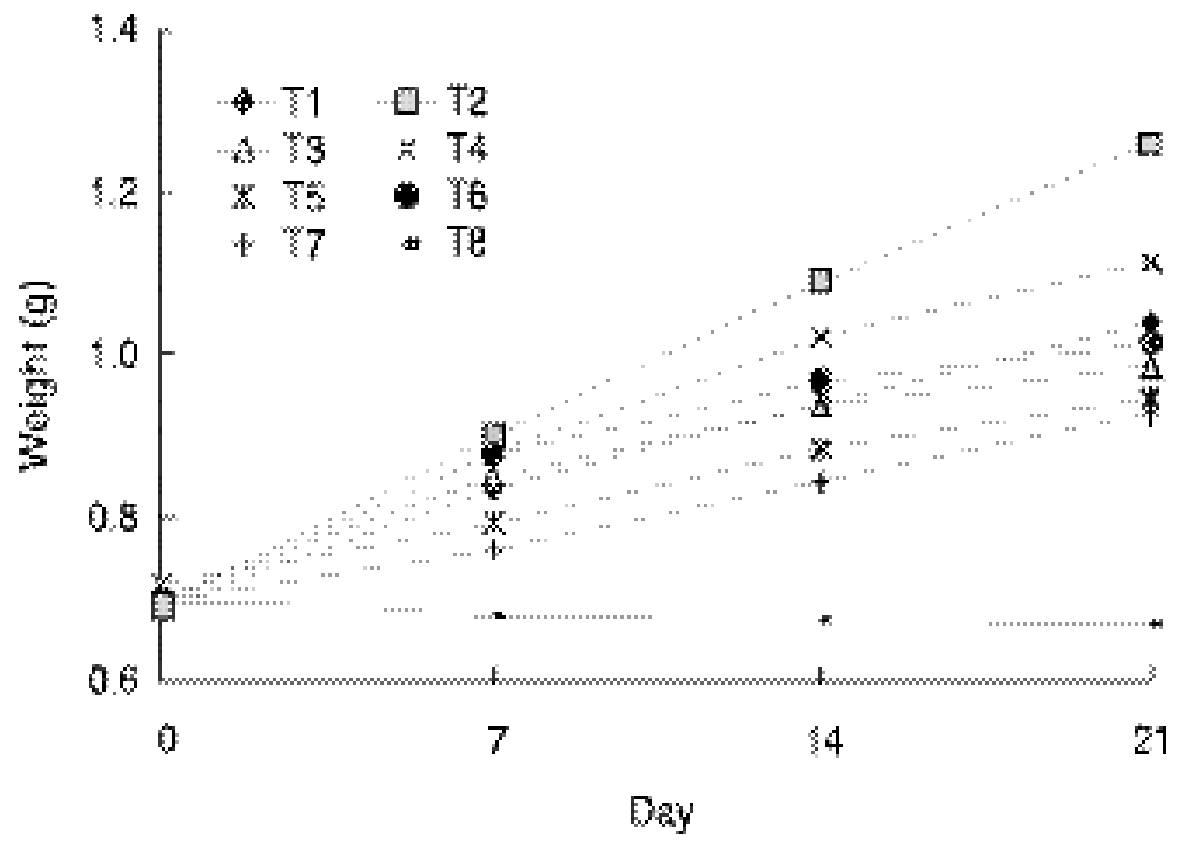

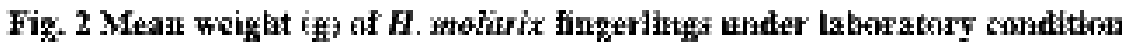

was observed in $t_{2}$ followed by 124.2, 100.0, 73.68, 65.0, $65.0,62.71$ and 60.35 in $\mathrm{t}_{8}, \mathrm{t}_{5}, \mathrm{t}_{3}, \mathrm{t}_{1}, \mathrm{t}_{4}, \mathrm{t}_{6}$ and $\mathrm{t}_{7}$, respectively (Table III). The length gain showed similar trend. In case of both weight gain and length gain treatment $\mathrm{T}_{2}$ showed higher growth than other treatments (Fig. 3 and 4). Specific growth rate (SGR, \%/day) was maximum (4.35) in the treatment $\mathrm{T}_{2}$ feeding $100 \%$ S. platensis followed by 3.84, 3.30, 2.63, 2.44, 240, 2.32 and 2.25 in the treatments $\mathrm{T}_{8}, \mathrm{~T}_{5}, \mathrm{~T}_{3}, \mathrm{~T}_{4}, \mathrm{~T}_{1}, \mathrm{~T}_{6}$ and $\mathrm{T}_{7}$, respectively. Survival rate ranges from 97.78 to $100 \%$ for all the treatments and the differences was insignificant. However, no 
Table III: Growth performance and survival rate of reared B. gonionotus fed on cultured microalgae in different combination

\begin{tabular}{l|c|c|c|c|c|c}
\hline Treatments & $\begin{array}{c}\text { Weirght } \\
\text { gain (g) }\end{array}$ & $\begin{array}{c}\text { Weight } \\
\text { gain\% }\end{array}$ & $\begin{array}{c}\text { Length } \\
\text { gain }(\mathrm{cm})\end{array}$ & $\begin{array}{c}\text { Length } \\
\text { gain \% }\end{array}$ & $\begin{array}{c}\text { SGR } \\
(\% / \text { day })\end{array}$ & $\begin{array}{c}\text { Survival } \\
\text { rate }(\%)\end{array}$ \\
\hline $\mathrm{t}_{1}$ & $0.39 \pm 0.03^{\mathrm{d}}$ & $65.00 \pm 0.03^{\mathrm{e}}$ & $1.17 \pm 0.12^{\mathrm{c}}$ & $34.41 \pm 0.11^{\mathrm{e}}$ & $2.40 \pm 0.30^{\mathrm{d}}$ & $97.78+3.85^{\mathrm{a}}$ \\
$\mathrm{t}_{2}$ & $0.85 \pm 0.09^{\mathrm{a}}$ & $149.1 \pm 0.08^{\mathrm{a}}$ & $1.90 \pm 0.20^{\mathrm{a}}$ & $55.88 \pm 0.18^{\mathrm{a}}$ & $4.35 \pm 0.59^{\mathrm{a}}$ & $100.0 \pm 0.00^{\mathrm{a}}$ \\
$\mathrm{t}_{3}$ & $0.42 \pm 0.04^{\mathrm{d}}$ & $73.68 \pm 0.03^{\mathrm{d}}$ & $1.20 \pm 0.10^{\mathrm{cd}}$ & $35.50 \pm 0.10^{\mathrm{d}}$ & $2.63 \pm 0.36^{\mathrm{cd}}$ & $100.0 \pm 0.00^{\mathrm{a}}$ \\
$\mathrm{t}_{4}$ & $0.39 \pm 0.09^{\mathrm{d}}$ & $65.00 \pm 0.09^{\mathrm{e}}$ & $1.08 \pm 0.23^{\mathrm{cd}}$ & $31.86 \pm 0.22^{\mathrm{f}}$ & $2.44 \pm 0.59^{\mathrm{d}}$ & $97.78 \pm 3.85^{\mathrm{a}}$ \\
$\mathrm{t}_{5}$ & $0.60 \pm 0.08^{\mathrm{c}}$ & $100.0 \pm 0.07^{\mathrm{c}}$ & $1.50 \pm 0.15^{\mathrm{b}}$ & $44.12 \pm 0.14^{\mathrm{c}}$ & $3.30 \pm 0.50^{\mathrm{bc}}$ & $100.0 \pm 0.00^{\mathrm{a}}$ \\
$\mathrm{t}_{6}$ & $0.37 \pm 0.03^{\mathrm{d}}$ & $62.71 \pm 0.03^{\mathrm{f}}$ & $0.90 \pm 0.00^{\mathrm{d}}$ & $26.47 \pm 0.00^{\mathrm{g}}$ & $2.32 \pm 0.28^{\mathrm{d}}$ & $100.0 \pm 0.00^{\mathrm{a}}$ \\
$\mathrm{t}_{7}$ & $0.35+0.04^{\mathrm{d}}$ & $60.35 \pm 0.04^{\mathrm{f}}$ & $0.90 \pm 0.10^{\mathrm{e}}$ & $26.63 \pm 0.10^{\mathrm{g}}$ & $2.25 \pm 0.15^{\mathrm{d}}$ & $97.78 \pm 3.85^{\mathrm{a}}$ \\
$\mathrm{t}_{8}$ & $0.72 \pm 0.06^{\mathrm{b}}$ & $124.2 \pm 0.05^{\mathrm{b}}$ & $1.79 \pm 0.06^{\mathrm{a}}$ & $52.96 \pm 0.06^{\mathrm{b}}$ & $3.84 \pm 0.48^{\mathrm{ab}}$ & $100.0 \pm 0.00^{\mathrm{a}}$ \\
\hline
\end{tabular}

Data in a column followed by different letter (s) indicate significant differences at $5 \%$ level

fish was died in the treatments $t_{2}, t_{3}, t_{5}, t_{6}$ and $t_{8}$. The different growth parameters of the present study illustrated that treatment $\mathrm{t}_{2}$ (feeding $100 \%$ S. platensis) obtained significantly $(\mathrm{p}<0.05)$ higher growth performance than other treatments. It might be happened due to the higher content of protein and other nutrients of supplied S. platensis. The over all growth performance of $B$. gonionotus was considered satisfactory in the laboratory - based trial. Live foods sometimes give good growth and survival rate of fish fry (Craig et al., 1994).
During the rearing of $B$. gonionotus, $\mathrm{pH}$ and dissolved oxygen (DO) of water in the aquaria were 7.28 to 7.89 and 4.13 to $6.40 \mathrm{mg} / 1$, respectively and the temperature range was 28.27 to $29.47^{\circ} \mathrm{C}$. These parameters were within the suitable range of fish culture (Azim et al., 1995 and Wahid et al., 1997).

The cultured microalgae contained 37.21 to $58.38 \%$ protein, 11.15 to $17.37 \%$ lipid and 7.33 to $14.20 \%$ ash, 5.26 to $7.46 \%$ crude fiber, 7.62 to $9.73 \%$ moisture and 8.76 to $18.23 \%$

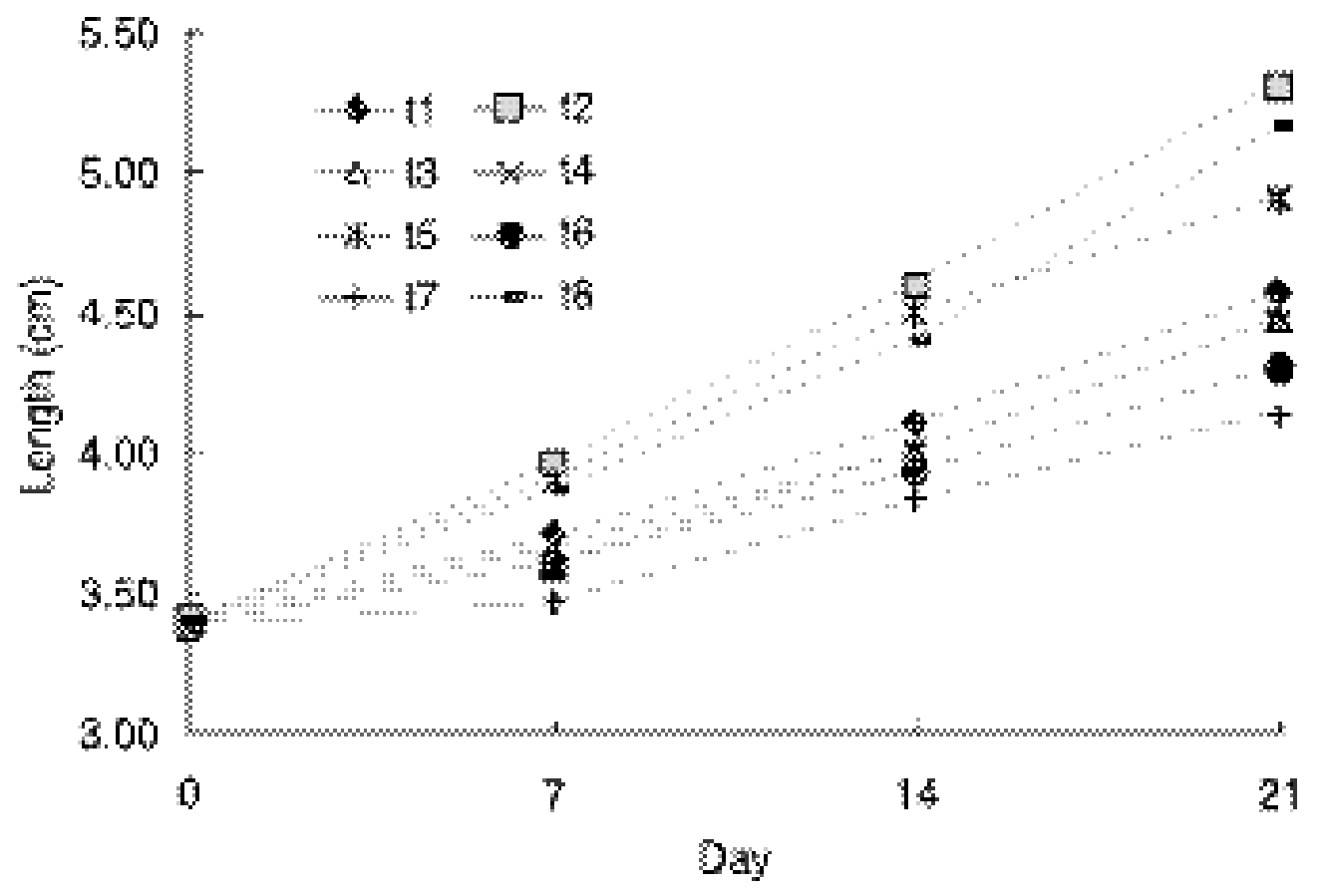

Fig. 3: Mean length (cm) of $B$. gonionotus, fingerlings under laboratory condition 


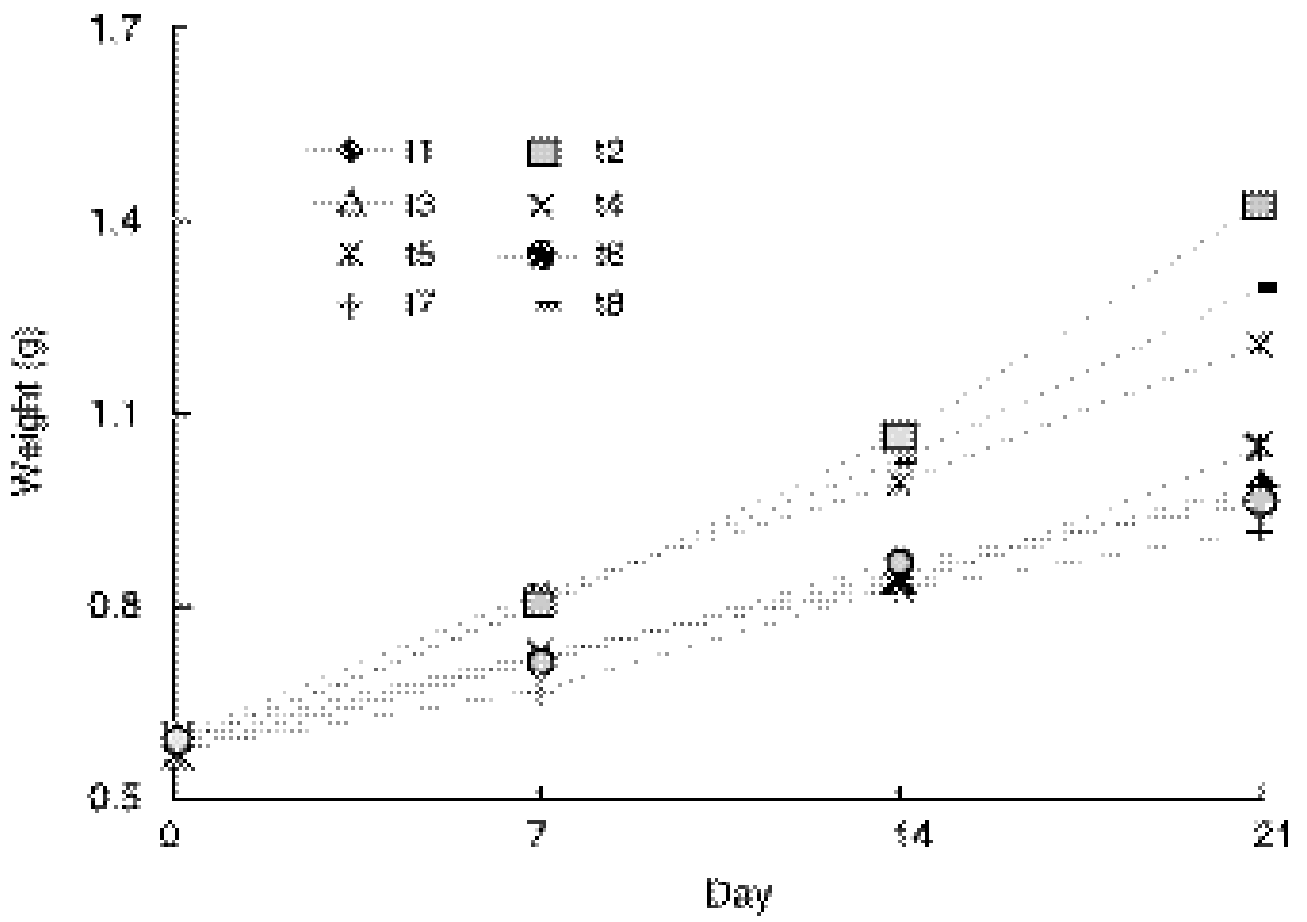

nitrogen free extract (NFE). In the case of $H$. molitrix, crude protein, crude lipid, ash and dry matter percentage were from 70.53 to $76.03 \%, 5.58$ to $8.24 \%, 15.96$ to $20.43 \%$ and 83.72 to $84.48 \%$, respectively (Table IV). The maximum crude protein and ash percentage were observed in the treatments $\mathrm{T}_{2}$, and $\mathrm{T}_{4}$, respectively. Both crude lipid and dry matter percentage were maximum in $\mathrm{T}_{5}$. In the case of B. gonionotus, the ranges of crude protein, crude lipid, ash and dry matter percentage were 73.62 to $77.05 \%, 5.38$ to $6.71 \%, 16.87$ to
$18.50 \%$ and 82.97 to $84.32 \%$, repectively (Table V). The maximum protein, ash and dry matter precentage of $B$. gonionotus were observed in the treatment $\mathrm{T}_{2}$, but the maximum lipid was found in $\mathrm{T}_{7}$.

The growth performance of $B$. gonionotus in all the treatments of the present study was comparatively better than $H$. molitrix The treatment feeding 100\% Spirulina showed significantly $(\mathrm{p}<0.05)$ higher growth performance for both the

Table IV: Mean values $( \pm \mathrm{SD})$ of proximate composition ( $\%$ dry matter basis) of reared $\boldsymbol{H}$. molitrix fed on cultured microalgae in different combination

\begin{tabular}{l|c|c|c|c}
\hline \multirow{2}{*}{ Treatment } & \multicolumn{3}{|c}{ Composition (\%) } \\
\cline { 2 - 5 } & Protein & Lipid & Ash & Dry matter \\
\hline $\mathrm{T}_{1}$ & $71.22 \pm 2.06^{\mathrm{ab}}$ & $7.03 \pm 0.31^{\mathrm{b}}$ & $19.94 \pm 0.69^{\mathrm{a}}$ & $84.10 \pm 0.26^{\mathrm{bc}}$ \\
$\mathrm{T}_{2}$ & $76.03 \pm 3.97^{\mathrm{a}}$ & $5.58 \pm 0.48^{\mathrm{e}}$ & $18.04 \pm 0.44^{\mathrm{b}}$ & $84.33 \pm 0.22^{\mathrm{ab}}$ \\
$\mathrm{T}_{3}$ & $73.86 \pm 1.35^{\mathrm{ab}}$ & $6.09 \pm 0.34^{\mathrm{de}}$ & $15.96 \pm 0.25^{\mathrm{d}}$ & $83.72 \pm 0.16^{\mathrm{d}}$ \\
$\mathrm{T}_{4}$ & $74.85 \pm 3.07^{\mathrm{ab}}$ & $6.38 \pm 0.28^{\mathrm{cd}}$ & $20.37 \pm 0.28^{\mathrm{a}}$ & $84.14 \pm 0.11^{\mathrm{abc}}$ \\
$\mathrm{T}_{5}$ & $74.54 \pm 4.17^{\mathrm{ab}}$ & $8.24 \pm 0.23^{\mathrm{a}}$ & $16.69 \pm 0.19^{\mathrm{c}}$ & $84.45 \pm 0.13^{\mathrm{a}}$ \\
$\mathrm{T}_{6}$ & $74.69 \pm 1.76^{\mathrm{ab}}$ & $5.91 \pm 0.19^{\mathrm{de}}$ & $18.62 \pm 0.66^{\mathrm{b}}$ & $84.13 \pm 0.10^{\mathrm{abc}}$ \\
$\mathrm{T}_{7}$ & $71.34 \pm 1.00^{\mathrm{ab}}$ & $6.26 \pm 0.19^{\mathrm{cd}}$ & $20.43 \pm 0.30^{\mathrm{a}}$ & $84.19 \pm 0.15^{\mathrm{abc}}$ \\
$\mathrm{T}_{8}$ & $70.53 \pm 3.11^{\mathrm{b}}$ & $6.73 \pm 0.21^{\mathrm{bc}}$ & $16.05 \pm 0.29^{\mathrm{d}}$ & $83.94 \pm 0.20^{\mathrm{cd}}$ \\
\hline
\end{tabular}

Data in a column followed by different letter (s) indicate singnificant differences at $5 \%$ level 
Table V: Mean values ( \pm SD) of proximate composition (\% dry matter basis) of reared B. gonionotus fed on cultured microalgae in different combination

\begin{tabular}{l|c|c|c|c}
\hline \multirow{2}{*}{ Treatment } & \multicolumn{4}{|c}{ Composition (\%) } \\
\cline { 2 - 5 } & Protein & Lipid & Ash & Dry matter \\
\hline $\mathrm{t}_{1}$ & $73.81 \pm 0.38^{\mathrm{d}}$ & $6.24 \pm 0.09^{\mathrm{bc}}$ & $17.49 \pm 0.67^{\mathrm{b}}$ & $83.63 \pm 0.46^{\mathrm{a}}$ \\
$\mathrm{t}_{2}$ & $76.75 \pm 0.78^{\mathrm{a}}$ & $5.38 \pm 0.11^{\mathrm{d}}$ & $18.50 \pm 0.22^{\mathrm{a}}$ & $84.32 \pm 1.09^{\mathrm{a}}$ \\
$\mathrm{t}_{3}$ & $75.47 \pm 0.21^{\mathrm{c}}$ & $6.40 \pm 0.29^{\mathrm{ab}}$ & $17.30 \pm 0.17^{\mathrm{b}}$ & $83.56 \pm 1.14^{\mathrm{a}}$ \\
$\mathrm{t}_{4}$ & $73.69 \pm 0.39^{\mathrm{d}}$ & $5.46 \pm 0.16^{\mathrm{d}}$ & $17.68 \pm 0.56^{\mathrm{ab}}$ & $83.88 \pm 0.60^{\mathrm{a}}$ \\
$\mathrm{t}_{5}$ & $75.08 \pm 0.84^{\mathrm{b}}$ & $6.63 \pm 0.19^{\mathrm{a}}$ & $16.92 \pm 0.58^{\mathrm{b}}$ & $82.97 \pm 0.43^{\mathrm{a}}$ \\
$\mathrm{t}_{6}$ & $74.61 \pm 0.32^{\mathrm{b}}$ & $5.98 \pm 0.18^{\mathrm{c}}$ & $17.51 \pm 0.74^{\mathrm{b}}$ & $83.59 \pm 0.72^{\mathrm{a}}$ \\
$\mathrm{t}_{7}$ & $73.62 \pm 0.46^{\mathrm{d}}$ & $6.71 \pm 0.21^{\mathrm{a}}$ & $16.93 \pm 0.47^{\mathrm{b}}$ & $83.80 \pm 0.74^{\mathrm{a}}$ \\
$\mathrm{t}_{8}$ & $77.05 \pm 1.54^{\mathrm{a}}$ & $5.42 \pm 0.12^{\mathrm{d}}$ & $16.87 \pm 0.53^{\mathrm{b}}$ & $83.78 \pm 0.75^{\mathrm{a}}$ \\
\hline
\end{tabular}

Data in a column followed by different letter (s) indicate significant differences at 5\% level

species of fingerlings which proved the suitability of Spirulina as a live food for fish. The species $H$. molitrix generally grows well in large water bodies. So, this species may not be suitable for trial in aquarium in the laboratory.

\section{Acknowledgement}

The authors remain grateful to the Director, Bangladesh Agricultural University Research System, Bangladesh Agricultural University, Mymensingh, Bangladesh for providing the fund for successful completion of the research.

\section{References}

Azim M. E., Talukder G. S., Wahab M. A., Haque M. M. and Haq M. S. (1995). Effects of liming and maintenance of total hardness levels on fish production in fertilized ponds. Progress. Agric. 6 (2): 7-14.

Bhanou K. K. and Vass K. K. (1973). A simple and inexpensive method for the mass culture of Chlorella sp. J. Inland Fish. Soc. Indi. 5: 141-142.

Brown M. E. (1597). Experimental studies on growth. In: Brown, M. E. (ed.). The Physiology of Fishes. Vol. 1. Academic Press, New York, USA. pp. 361-400.

Craig S. R., Arnold C. R. and Holt G. J. (1994). The effects of enriching live foods with highly unsaturated fatty acids on the growth and fatty acid composition of larval red drum, Sciaenops ocellatus.J. World Aquaculture Soc. 25(3): 424-431.
De Silva S. S. and Davy C. (1992). Fish nutrition research for semi intensive culture system in Asia. Asian Fish. Sci. 5: 129-144.

Gomez K. A. and Gomez A. A. (1976.) Statistical procedures for agricultural research (2nd ed.). Int. Rice Res. Ins., Philippines. 641 pp.

Habib M. A. B., Yusoff F. M., Phang S. M. and Mohamed S. (2003). Culture and nutritional value of Moina micrura Pallas fed on Chlorella vulgaris grown in digested palm oil mill effluent. Asian Fish. Sci. 16(1-2): 107119.

Horwitz W. (1984). Official Methods of the Analysis of the Association of Official Analytical Chemists (14th ed.). Association of Official Analytical Chemists; Washington D. C., USA. 1018 pp.

Jhons W. E. (1970). Chlorella for rearing fish larvae. FAO Fish Culture Bull., 2: 3pp.

Kaushik S. J. (1992). Fish nutrition science and aquaculture development. In: Aquaculture Research Needs for 2000AD. Oxford and IBH Publication, New Delhi, India. 414 pp.

Lovell T. (1991). Feed formulation and processing In: Lovell, T. (ed) Nutrition and feeding of fish. PP. Van Nostrand Reinhold Publication, New York, pp. 107127. 
Ozkizilcik S. and Chu F. E. (1994). Evaluation of omega-3 fatty acid enrichment of Artemia nauplii as food for striped bass Morone saxatilis Walbaum larvae. J. World Aquaculture Soc. 25(1): 147-154.

Pruder G. D. (1983). Biological control of gas exchange in intensive aquatic production system. J. Ins. Electro. Eng. pp. 1002-1004.

Walne P. R. (1981). Culture of shellfish. In: Hawkins A. D. (ed) Aquarium System. Academic Press, pp. 347-371.

Wahid M. I., Haq M. S., Wahab M. A. and Ahmed Z. F. (1997). Effect of fertilizer treatments on the water quality and fish production in semi-intensively managed ponds. Progress. Agric. 8(1\&2): 61-65.
Watanabe T. C., Kitajima and Fujita S. (1983). Nutritional value of live organisms used in Japan for mass propagation of fish: a review Aquaculture, 34: 115-143.

Yap Y. N., Wu J. F., Pond W. G. and Krook L. (1982). Feasibility of feeding Spirulina maxima, Spirulina platensis or Chlorella sp. to pigs weaned to a dry diet at 4 to 8 days of age. Nutri. Reports Int. 25: 543-552.

Zar J. H. (1984). Biostatistics. prentice-Hall, Inc., Englewood Cliffs, New Jersey, USA. 718 pp.

Received : September 27, 2009;

Accepted : February 09, 2010 